\title{
THE IMPACT OF ZERO IMPORT TARIFF POLICY AND AIR POLLUTION PREVENTION AND CONTROL ACTION PLAN ON INDONESIAN COAL EXPORT TO CHINA
}

\author{
Pengaruh Kebijakan Penghapusan Tarif Impor dan Air Pollution Prevention \\ And Control Action Plan Terhadap Ekspor Batu Bara Indonesia ke Republik \\ Rakyat Tiongkok
}

\author{
Nanda Bagus Rahmawan, Siskarossa Ika Oktora \\ Sekolah Tinggi Ilmu Statistik, Jakarta, East Jakarta, Indonesia, 13330 \\ email: nanda.rahmawan8@gmail.com
}

Naskah diterima: 29/09/2017; Naskah direvisi: 05/02/2018; Disetujui diterbitkan: 12/03/2018

Dipublikasikan online: 31/07/2018

\begin{abstract}
Abstrak
Republik Rakyat Tiongkok (RRT) telah menerapkan kebijakan tarif impor nol persen pada komoditas batu bara pada Januari 2008 dan kebijakan Air Pollution Prevention and Control Action Plan pada tahun 2014. Tujuan dari kajian ini adalah untuk menganalisis pengaruh kebijakan tarif impor nol persen dan Air Pollution Prevention and Control Action Plan terhadap ekspor batu bara Indonesia ke RRT. Metode yang digunakan dalam kajian ini adalah analisis intervensi multi input dengan menggunakan data Badan Pusat Statistik (BPS). Hasil kajian menunjukkan bahwa kebijakan tarif impor nol persen yang diterapkan oleh RRT memiliki pengaruh yang signifikan positif dan permanen terhadap ekspor batu bara Indonesia ke RRT. Sementara itu, kebijakan Air Pollution Prevention and Control Action Plan memiliki pengaruh yang signifikan negatif dan permanen. Berdasarkan hal ini, pemerintah harus mengimplementasikan standar minimum kualitas batu bara yang dihasilkan. Dengan demikian, ekspor batu bara Indonesia dapat menyesuaikan spesifikasi kualitas yang diminta oleh negara pengimpor yang menerapkan kebijakan pengendalian pencemaran udara.
\end{abstract}

Kata Kunci: Perdagangan Internasional, Ekspor, Batu Bara, Analisis Intervensi

\begin{abstract}
The People Republic of China (China) has implemented zero import tariff policy on coal product on January 2008 and Air Pollution Prevention and Control Action Plan policy in 2014. The objective of this research is to analyze the impact of the influence of zero import tariff policy and Air Pollution Prevention and Control Action Plan on the Indonesian coal exports to China. The method used in this research is the multi-input intervention analysis using Central Bureau of Statistics (BPS) data. The analysis shows that the zero import tariff policy applied by China has significantly positive and permanent effect on the Indonesian coal exports to China. Meanwhile, the the Air Pollution Prevention and Control Action Plan policy has significantly negative and permanent effect. Based on the analaysis the government has to implement the minimum standards policy on coal quality.Thus, Indonesian coal exports will be able to adjust market demand specification quality from importing countries that implement pollution control policy.
\end{abstract}

Keywords: International Trade, Export, Coal, Intervention Analysis

JEL Classification: C22, F13, Q40, Q48 


\section{INTRODUCTION}

The international trade is one of the stimuli for the economic development. It makes today's international trade getting more liberal. It means that obstacles of trade in the world are diminishing and it will be both challenges and opportunities for Indonesia. One of Indonesia's greatest advantages in international trade is the wealth of its natural resources. One of them is coal. Indonesia is one of the world's largest coal producers, which in 2014 around 91 percent of the production is exported to various countries (BPS, 2016).

Coal plays an important role in generating world energy, especially electricity. According to International Energy Agency (2016), 41\% of the world's electricity was generated from coal in 2014. The importance of coal caused a high increase, both in terms of consumption and import. According to International Energy Agency data, in 2014 world coal consumption grew $70 \%$ from 2001 , which was the largest growth among other primary energy consumptions. In 2014 the coal import grew $117 \%$ from 2001. A high demand on the world market makes coal as one of the prospective commodities for Indonesia.
Started in 2011 to 2014 Indonesia is the largest coal exporter in the world, and the most of it is exported to China (BPS, 2016). In 2008 China began to eliminate tariff imports on coal. Consequently, there is a large increase of Indonesian coal exports to China. It caused China became the first destination of Indonesian coal import for the first time, whereas before 2008 China was the sixth country as the main destination of Indonesian coal exports. At the same time, China has become a net importer of coal and the largest coal importer in the world until now. In 2007 the volume of Indonesian coal export to China was 14.1 million metric tons, while in 2013 it reached 130.3 million metric tons.

Along with strong economic growth and rapid urbanization in the last several decades, China has become the world's leading $\mathrm{CO}_{2}$ emitter due to soaring energy consumption (Liu et al., 2015). It is well known that energy (more precisely coal) is the primary source of air pollution and carbon emissions in China, and the closely related energy and climate polices are also experiencing significant changes (Jin, 2016).

To reduce air pollution in China, in September 2013 China government 
released the Air Pollution Prevention and Control Action Plan (Cai et al., 2016). Among several major policies in that policy, there was a policy of emission reduction through energy structure adjustment (Clean Air Asia, 2015). There were policies on coal usage, such as coal consumption restrictions, target of region coal quality control and region coal usage control, that started to implement in early 2014 , as well as some policies on coal that followed it. As a result, the volume of Indonesian coal exports to China began to decline since 2014, and the main export destination of Indonesia shifted to India.

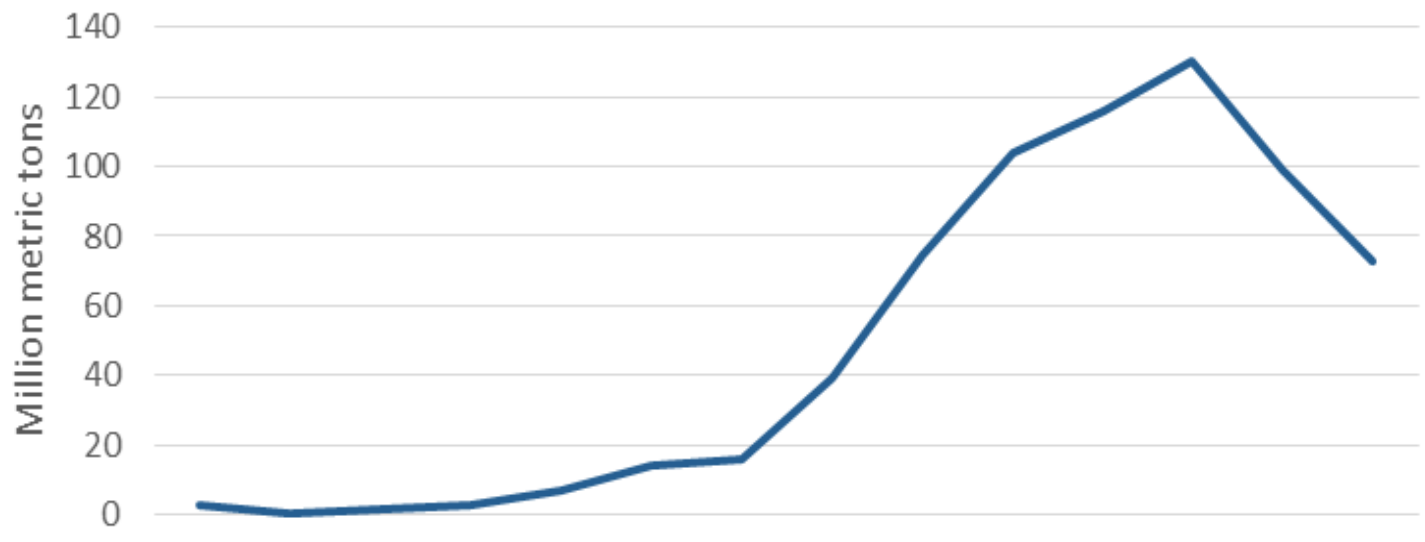

20022003200420052006200720082009201020112012201320142015

\section{Figure 1. Indonesian Coal Export Volume to China}

Source : BPS (2017)

Krugman \& Obstfeld (2008) explained and compared models of the effects of free trade, a tariff, and an import quota on import. It shows that with import tariff, the volume of imports of a country will be less than free trade, because the import tariff increase consumers cost. Meanwhile, model with non-tariff barriers (import quota) shows that imports cannot exceed the quota level. So, if a country usually import a product more than import quota, the import quota will seem to decrease the import.

Vanhnalat, et al (2015), studied about the impact of free trade agreements between Lao PDR and 32 trading partners. The study showed that reduction of import tariffs based on World Trade Organization commitment has strongly supported trade creation while several FTAs made with major 
trading partners are a vital factor to support export growth. The findings suggest Lao's exports under preferences and generalized system of preferences (GSP) treatment would increase trade volume on average by $50 \%$ more than those partners who neither have FTAs nor GSP.

Imburno (2016), studied about the effectiveness of different trade policy instruments on product-level Chinese imports over the period of 2000-2006. More specifically, in addition to the declines in tariffs. The research showed that manufacturing imports mainly increase because of tariff cuts, and agricultural imports grow due to the elimination of import licenses.

Okabe \& Urata (2014) studied about the impact of AFTA on intraAFTA trade. They found positive and significant trade creation effects from the tariff elimination for a wide range of products. In addition, the analysis revealed that the elasticity of tariff reduction on imports tends to be much larger than that on exports. The impact of free trade on export/ import also studied by (Hoque \& Yusop, 2012), (Dianniar, 2013), and (Cestepe et al., 2015). (Yusop, 2012) showed that free trade increase the export and import in Bangladesh and (Cestepe et al., 2015) showed that free trade increase the export of Middle East and North Africa (MENA) regions. Meanwhile, (Dianniar, 2013) showed that free trade does not have significant impact on Indonesia's agricultural trade.

The objective of this research is to explore the impact of zero import tariff on coal commodities and Air Pollution Prevention and Control Action Plan to the Indonesian coal export volume to China.

\section{METHODS}

The subject of this study is the volume of Indonesian coal exports to China. The period studied is from January 2004 to September 2016. Data used in this study is monthly data report from Subdirectorate of Statistical Exports of Badan Pusat Statistik (BPS) in 2017. The analysis method used to analyze the impact of zero coal import tariff and Air Pollution Prevention and Control Action Plan on Indonesian coal exports volume to China is the analysis of intervention, using multi-input intervention model. Data used in this paper is shown in Figure 2. 


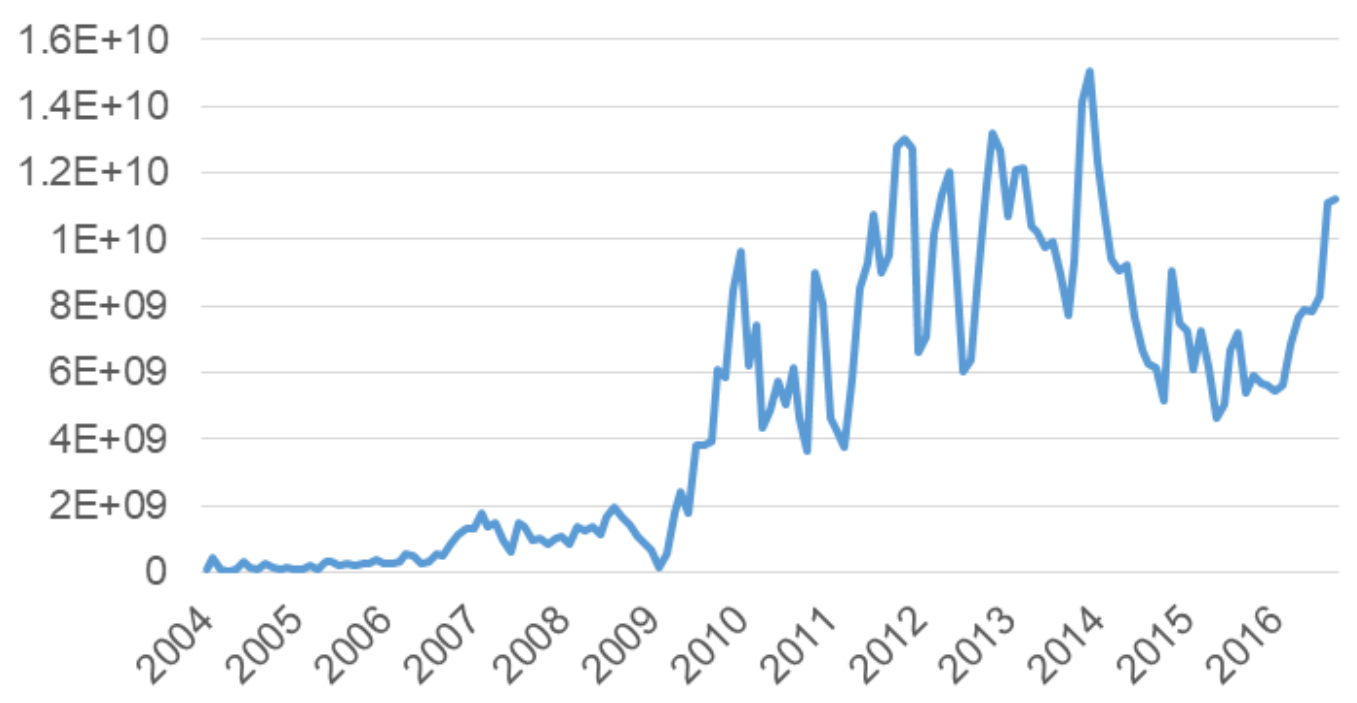

Figure 2. Monthly Exports Volume of Indonesian Coal to China (Kg)

Source : Subdirectorate of Statistical Exports of BPS (2017)

Intervention Analysis was first effect at time t. $I_{t}$ is either the step introduced by Box \& Tiao (1975) to function $S_{t}$ or the pulse function $P_{t}$. analyzed the air pollution in Los Angeles. There are two common types of intervention, namely step and pulse functions (Wei, 2006). Step function is a form of intervention that occurs in a long period, while the pulse function is a form of intervention that occurs in a single period only. An intervention model (Novianti \& Suhartono, 2009) is written as

$Z_{t}=\frac{\omega_{g}(B)}{\delta_{r}(B)} B^{b} I_{t}+\frac{\theta_{q}(B) \theta_{t}}{\oint_{p}(B)(1-B)^{d}}$

where $Z_{t}$ is response variable at time $\mathrm{t}$ and $I_{t}$ is intervention variable at time $\mathrm{t}$, which is worth 1 or 0 , indicates the presence or absence of intervention

All intervention type in this study are step functions, so we only discuss about step function. The step function (Ismail et al., 2009) written as

$I_{t}=S_{t}=\left\{\begin{array}{l}0, t<T \\ 1, t \geq T\end{array}\right.$

So the step function in single input intervention model can be written as

$Z_{t}=\frac{\omega_{s}(B)}{\delta_{r}(B)} B^{b} S_{t}+\frac{\theta_{q}(B) \varepsilon_{t}}{\oint_{p}(B)(1-B)^{d}}$

Where $\omega_{s}(B)$ and $\delta_{r}(B)$ are defined as:

$\omega_{s}(B)=\omega_{0}-\omega_{1} B-\omega_{2} B^{2}-\cdots-\omega_{s} B^{s}$ and

$\delta_{r}(B)=1-\delta_{1} B-\delta_{2} B^{2}-\cdots-\delta_{s} B^{r}$ 
The form $\theta_{q}(B) e_{t} / \emptyset_{p}(B)(1-B)^{d}$ is called noise model and usually identified using the uni-variate model identification procedure based on time series $Z_{t}$ before the date of intervention (Wei, 2006). Noise model in this study is ARIMA $\left\{\theta_{q}(B) e_{t} / \emptyset_{p}(B)(1-B)^{d}\right\}$.

An error of ARIMA model at $t$ time is $e_{t}$ under the assumption white noise and normally distributed. Meanwhile, $\theta_{q}(B)$ and $\emptyset_{p}(B)$ are defined as:

$\theta_{q}(B)=1-\theta_{1} B-\theta_{2} B^{2}-, \ldots,-\theta_{q} B^{q}$ and $\emptyset_{p}(B)=1-\emptyset_{1} B-\emptyset_{2} B^{2}-, \ldots,-\emptyset_{p} B^{p}$

Based on equation (3), order $b$ is the time delay for intervention effect. Order $s$ is the time required for the intervention effect to be stable calculated from when the intervention begins to take effect. And order $r$ is the pattern of the intervention effect.

The magnitude of the impact of the step function intervention $\left(S_{t}\right)$ on the time series data $\left(Z_{t}\right)$ based on equation (3) is written as

$Z_{t}^{*}=\frac{\omega_{g}(B)}{\delta_{r}(B)} B^{b} S_{t}$

With reference to equation (1), the multi input intervention model is (Lee et al, 2010)

$$
Z_{t}=\sum_{i=1}^{u} \frac{\omega_{s_{i}}(B)}{\delta_{r_{i}}(B)} B^{b_{i}} I_{t_{i}}+\frac{\theta_{q}(B) \varepsilon_{t}}{\oint_{p}(B)(1-B)^{d}} \ldots .
$$

In this study, both zero coal import tariff and Air Pollution Prevention and Control Action Plan are step function intervention. So we build multi input intervention model using 2 step functions. The model in this study can be specified as:

$$
Z_{t}=\frac{\omega_{s_{1}}(B)}{\delta_{r_{1}}(B)} B^{b_{1}} S_{t_{1}}+\frac{\omega_{s_{g}}(B)}{\delta_{r_{2}}(B)} B^{b_{s}} S_{t_{2}}+\frac{\theta_{q}(B) \varepsilon_{t}}{\phi_{p}(B)(1-B)^{d}}
$$

The method used for estimate parameters is nonlinier least square. The equation (6) can be rewritten as:

$$
\begin{aligned}
& \delta_{r_{1}}(B) \delta_{r_{2}}(B) \emptyset_{p}(B)(1-B)^{d} Z_{t}=\omega_{s_{1}}(B) \delta_{r_{2}}(B) \emptyset_{p}(B)(1-B)^{d} S_{t_{1-b_{1}}}+ \\
& \omega_{s_{2}}(B) \delta_{r_{1}}(B) \emptyset_{p}(B)(1-B)^{d} S_{t_{2-b_{2}}}+\delta_{r_{1}}(B) \delta_{r_{2}}(B) \theta_{q}(B) e_{t}
\end{aligned}
$$

or

$$
k(B) Z_{t}=l(B) S_{t_{1-b_{1}}}+m(B) S_{t_{2-b_{\mathrm{I}}}}+n(B) e_{t}
$$

Where:

$$
\begin{array}{ll}
k(B)=\delta_{r_{1}}(B) \delta_{r_{2}}(B) \emptyset_{p}(B)(1-B)^{d} & m(B)=\omega_{s_{2}}(B) \delta_{r_{1}}(B) \emptyset_{p}(B)(1-B)^{d} \\
l(B)=\omega_{s_{1}}(B) \delta_{r_{2}}(B) \emptyset_{p}(B)(1-B)^{d} & n(B)=\delta_{r_{1}}(B) \delta_{r_{2}}(B) \theta_{q}(B)
\end{array}
$$


Thus, we have:

$e_{t}=\frac{k(B) Z_{t}-l(B) S_{t_{1-b_{1}}}-m(B) S_{t_{2-b_{3}}}}{n(B)}$

Parameter estimation can be done by minimizing

$S(\delta, \omega, \emptyset, \theta)=\sum_{t=1}^{n} e_{t}^{2}$.

To find the parameters which minimize the sum square error, we take partial derivative with respect to each parameter $(\delta, \omega, \emptyset$, and $\theta)$ and set each resulting equation to zero.

The intervention model building in this research is following these procedures.

1. Dividing data set into some parts. Intervention model divide data into $k+1$ parts, where $k$ is the total of intervention function. In this case, dataset is divided into three parts.

First part is dataset before intervention. It is the first observation until the observation just before the first intervention (January 2004 to December 2007), i.e. $t=1,2, \ldots, T_{1}-1$. It can be denoted as $Z_{0_{t}}$. Second part is dataset from the first intervention until just before the second intervention (January 2008 to December 2013), i.e. $t=T_{1}, T_{1}+1, T_{1}+2, \ldots, T_{2}-1 . \quad$ It can be denoted as $Z_{1_{t}}$. The last part is dataset from the second intervention until the end of period in this study (January 2014 to September 2016), i.e. $t=T_{2}, T_{2}+1, T_{2}+2, \ldots, T_{2}+32$. It can be denoted as $Z_{2 t_{t}}$.

2. Modelling the ARIMA preintervention model.

We utilize Box-Jenkins methodology to build the pre intervention model through identification stage, parameter estimation, parameter significance test, and residual diagnostic check for ARIMA model. Then, we have $Z_{t}=\frac{\theta_{q}(B) \theta_{t}}{\phi_{p}(B)(1-B)^{d}}$.

After obtaining several models that can be used in intervention modelling, then we will select the best ARIMA model based on RMSE, AIC, and SBC criteria. The best ARIMA model will then be used in the first intervention modelling process.

3. Modelling the first intervention model.

First step of modelling the first intervention model is calculating the intervention response value $\left(Z_{1_{\mathrm{t}}}^{*}\right)$, i.e. $Z_{T_{1}}^{*}, Z_{T_{1}+1}^{*}, Z_{T_{1}+2}^{*}, \ldots, Z_{T_{2}-1}^{*}$. 
The calculation of the intervention response value uses the residual values obtained from the difference between the original data value and the forecast of ARIMA model on dataset from first intervention until just before the second intervention

$\left(\hat{Z}_{T_{1}}, \hat{Z}_{T_{1}+1}, \hat{Z}_{T_{1}+2}, \ldots, \hat{Z}_{T_{2}-1}\right)$.

The identification of $b_{1}, s_{1}$, and $r_{1}$ order for the first intervention model can be determined by observing residual plots against time with confidence interval of $\pm 3 \sigma_{1}$, where $\sigma_{1}$ is RMSE of the ARIMA pre intervention model. This interval is based on the determination of control chart bounds during statistical quality control for detecting outlier observations (Lee et al, 2010).

Then we estimate the parameters using non-linier least square and test the significance of those parameters using $\mathrm{t}$-student test. The hypothesis of the test is written as

$\mathrm{H}_{0}: \omega_{i}=0$

$\mathrm{H}_{1}: \omega_{i} \neq 0 ; 0,1, \ldots, k-1$

where $k$ is the number of parameters estimated. The $t$ statistic formula is: $t_{\text {statistic }}=\frac{\widehat{\omega}_{\bar{i}}}{s e\left(\hat{\omega}_{i}\right)}$

If $\left|t_{\text {statistic }}\right|>t_{\frac{\alpha}{2}(n-k)}$ or if $p$-value < $\alpha$ then we reject the null hypothesis $\left(\mathrm{H}_{0}\right)$, it means that the parameter is significant in the model. If we fail to reject the null hypothesis, the parameter is not significant.

We also conduct a residual diagnostic check to examine the error assumption, i.e. white noise and normality distribution. We use the Ljung-Box (LB) test to test white noise of error. The hypothesis of the Ljung-Box (LB) test is: $\mathrm{H}_{0}$ : error are independently distributed and $\mathrm{H}_{1}$ : error are dependently distributed.

The LB formula is (Enders, 2004).

$L B=n(n+2) \sum_{k=1}^{K} \frac{\hat{p}_{k}^{n}}{n-k}$

where

$$
\hat{\rho}_{k}=\frac{\sum_{i=1}^{n-k}\left(Z_{t}-\bar{Z}\right)\left(Z_{t+k}-\bar{Z}\right)}{\sum_{i=1}^{n}\left(Z_{t}-\bar{Z}\right)} \ldots . .
$$

$\hat{\rho}_{k}$ is autocorrelation coefficient at lag $\mathrm{k}$.

We reject the null hypothesis if $L B>\chi_{\frac{\alpha}{2},(\mathrm{~K}-\mathrm{p}-\mathrm{q})}^{2}$ or if $\mathrm{p}$-value $<\mathrm{\alpha}$. $K$ represents the number of lag tested, $p$ represents the number of Autoregressive parameter and $q$ represents the number of Moving 
Average parameter. If we reject the null hypothesis it means the error is not white noise. If we fail to reject the null hypothesis it means error of model is white noise.

For normality test we use Kolmogorov-Smirnov test. The hypothesis of the test is:

$\mathrm{H}_{0}: e_{t} \sim N\left(0, \sigma^{2}\right)$

$\mathrm{H}_{1}: e_{t} x N\left(0, \sigma^{2}\right)$

Kolmogorov-Smirnov statistic is (Siegel, 1992)

$D_{\text {statistic }}=\max \left|F_{0}(x)-S_{n}(X)\right|$

where $F_{0}(x)$ is a cumulative frequency distribution function that occurs under a normal distribution and $S_{n}(X)$ is a cumulative frequency distribution function that being observed.

If $D_{\text {statistic }}>D(\alpha, n)$ or $p$-value $<\alpha$ then we reject the null hypothesis. It means that error of the model is not normally distributed. If we fail to reject the null hypothesis, it means that error of the model is normally distributed.

4. Modelling the second intervention model.

Intervention response value of second intervention model $\left(Z_{1_{\mathrm{t}}}^{*}\right)$ is written as $Z_{T_{2}}^{*}, Z_{T_{2}+1}^{*}, Z_{T_{2}+2}^{*}, \ldots, Z_{T_{2}+32}^{*}$.
The calculation of the intervention response value uses the residual value obtained from the difference between the original data value and the forecast of first intervention model on dataset from second intervention until the end of period $\left(\hat{Z}_{T_{2}}, \hat{Z}_{T_{2}+1}, \hat{Z}_{T_{2}+2}, \ldots, \hat{Z}_{T_{2}+32}\right)$.

The identification of $b_{2}, s_{2}$, and $r_{2}$ order for the second intervention model can be determined by observing residual plots against time with confidence interval of $\pm 3 \sigma_{2}$, where $\sigma_{2}$ is RMSE of the first intervention model.

The estimation method, test of significance, and residual diagnostic check of second intervention model has similar procedures as first intervention model.

\section{RESULTS AND DISCUSSION}

The step resume analysis of this study, we built a pre-intervention model then forcasted to build the first intervention model. From this first intervention model then we forcasted to build the second intervention model.

According to identification stage of pre-intervention modelling, data was 
not stationary both in variance and mean. Based on result of Box-Cox plot, we transform data into square root form. This transformation cause data to be constant in variance. Transformed data is shown in Figure 3.

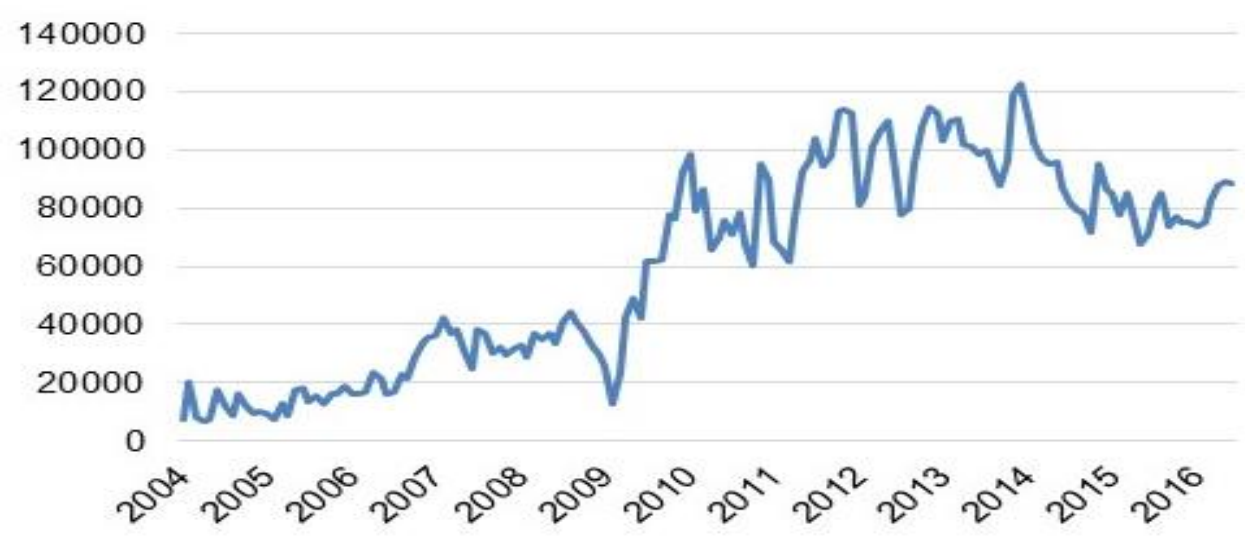

Figure 3. Square Root of Monthly Export Volume of Indonesian Coal to China

To convert data to be constant on mean, we use regular differencing in first order. Then, we identifiy some possible models of ARIMA by observing Auto Correlation Function (ACF) and Partial Auto Correlation Function (PACF) plot. ACF and PACF plot of stationary data are shown in Figure 4 and Figure 5.

According to ACF and PACF plot, there are several possible ARIMA models that are formed, i.e. ARIMA $(1,1,0)$, ARIMA $(1,1,1)$, ARIMA $(2,1,0)$, $\operatorname{ARIMA}(2,1,1)$, and ARIMA $(0,1,1)$.

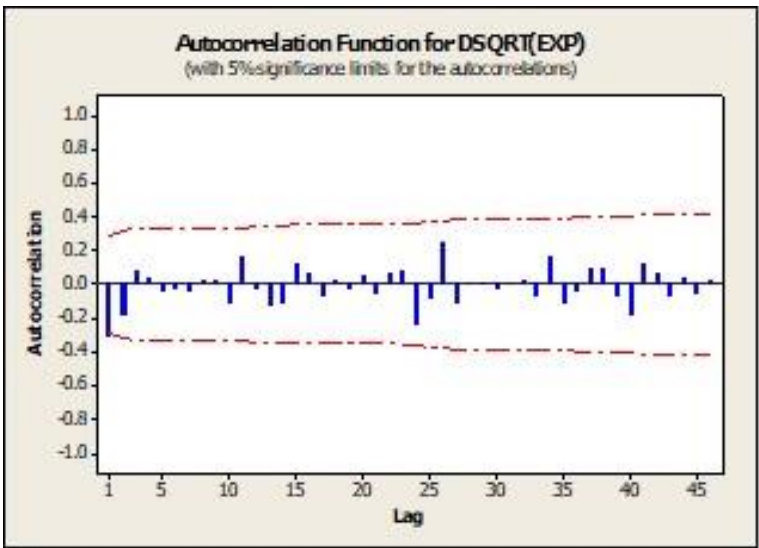

Figure 4. ACF Plot of Stationary Data before Intervention

Among those five models of ARIMA, there are only two models that have significant ARIMA parameters,

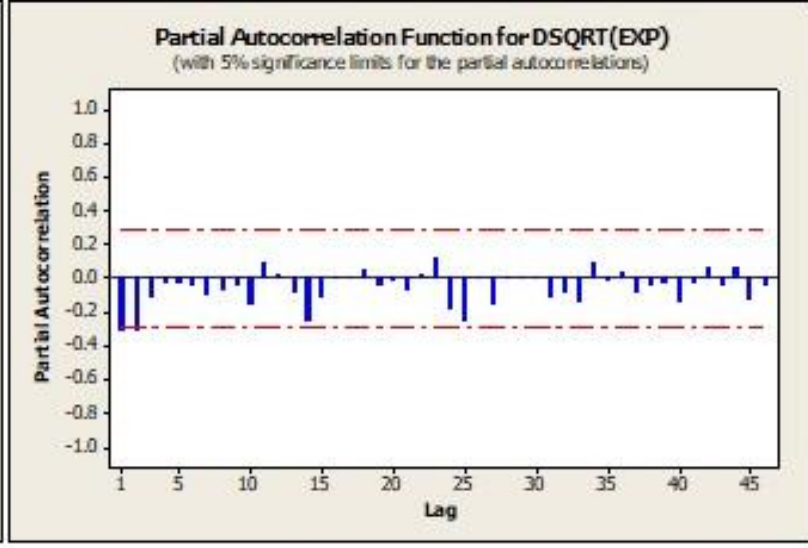

Figure 5. PACF Plot of Stationary Data before Intervention

white noise error and normal distributed error. The models are ARIMA $(1,1,0)$ and ARIMA $(0,1,1)$. Both models are 
appropriate for forecasting data, but ARIMA $(0,1,1)$ yields less RMSE. Smaller RMSE of a model means the forecast of a model is more approximate the actual data. Thus, the best ARIMA pre intervention model is ARIMA $(0,1,1)$.

Table 1. Parameter estimation results for ARIMA $(0,1,1)$

\begin{tabular}{cccc}
\hline Parameter & Estimate & $\mathbf{t}$ & $\mathbf{p}$-value \\
\hline $\mathrm{C}$ & 474.1237 & 1.36 & 0.1806 \\
$\emptyset_{1}$ & 0.5160 & 4.01 & 0.0002 \\
\hline
\end{tabular}

ARIMA pre intervention model can be written as:

$\sqrt{Z_{t}}=\frac{474.12+(1-0.5160 B) e_{t}}{(1-B)}$

After obtaining pre intervention model, then we do forecast for data from January 2008 to December 2013 using ARIMA $(0,1,1)$ and build intervention response value for first intervention identification model.

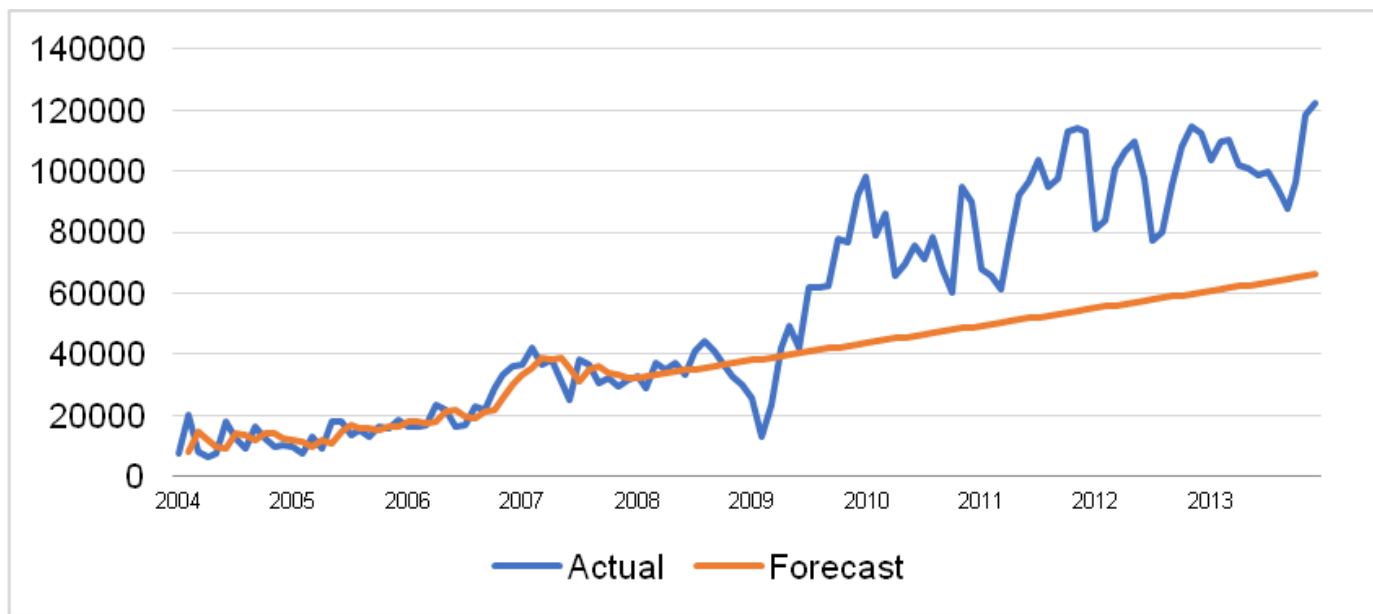

Figure 6. Actual Data and Forecast of ARIMA Pre Intervention (in square root)

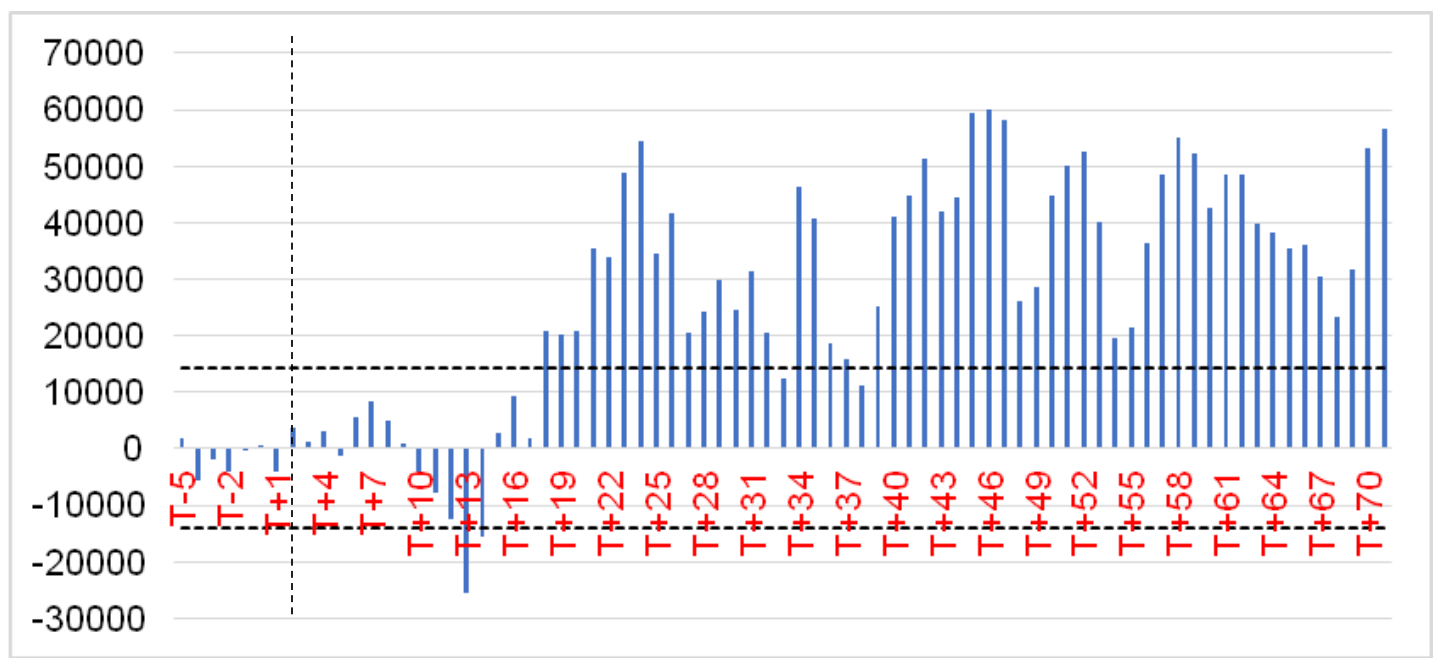

Figure 7. Response Value (in square root) after The First Intervention 
The confidence interval in Figure 7 is based on RMSE of ARIMA, i.e. \pm 14,191. Intervention response value shows the impact of the zero import tariff of coal. First step in building model of first intervention is determine the order of response value $(b, s$, and $r)$. The order of intervention response explain the increase in the volume of Indonesian coal exports due to zero import tariff of coal implemented by China.

Intervention response value shown in Figure 7 starts from $T+18$, all the intervention response have greater value than the confidence interval. The response value shows that there is no specific pattern, so we can assume that order $r_{1}=0$. There are so many changes in response value in the period, which indicates there are many possibilities of order $s_{1}$.

Based on the results of parameter estimation, significance test, residual diagnostic and RMSE of many models we have done, we conclude that the best model for first intervention is $b_{1}=$ $18, s_{1}=(3,5,7,9,16,18,21,22,25$, 27, 30, 32), $r_{1}=0$. Parameter estimation and white noise error test of that model are shown in Table 2 and 3.
Table 2. Parameter Estimation Results for First Intervention Model

\begin{tabular}{cccc}
\hline Parameter & Estimate & t stat & p-value \\
\hline$C$ & 595.7 & 0.44 & 0.6608 \\
$\emptyset_{1}$ & 0.5451 & 4.31 & 0.0001 \\
$\widehat{\omega}_{1_{0}}$ & $24,061.3$ & 3.90 & 0.0004 \\
$\widehat{\omega}_{1_{1}}$ & $-15,185.6$ & -2.40 & 0.0197 \\
$\widehat{\omega}_{1_{2}}$ & $-13,353.6$ & -2.05 & 0.0451 \\
$\widehat{\omega}_{1_{9}}$ & $25,170.7$ & 3.87 & 0.0003 \\
$\widehat{\omega}_{1_{4}}$ & $22,501.9$ & 3.59 & 0.0007 \\
$\widehat{\omega}_{1_{5}}$ & $-35,618.2$ & -5.44 & 0.0001 \\
$\widehat{\omega}_{1_{6}}$ & $19,157.4$ & 3.02 & 0.0038 \\
$\hat{\omega}_{17}$ & $-15,824.5$ & -2.19 & 0.0330 \\
$\hat{\omega}_{19}$ & $-15,087.1$ & -2.09 & 0.0415 \\
$\widehat{\omega}_{19}$ & $12,939.4$ & 2.05 & 0.0457 \\
$\widehat{\omega}_{1_{10}}$ & $-13,499.4$ & -2.14 & 0.0372 \\
$\widehat{\omega}_{1_{11}}$ & $31,942.9$ & 5.05 & 0.0001 \\
$\widehat{\omega}_{1_{12}}$ & $-13,498.9$ & -2.16 & 0.0350 \\
\hline
\end{tabular}

Table 3. White Noise Test Results for $1^{\text {st }}$ Intervention Model

\begin{tabular}{cccc}
\hline Lag & Ljung-Box Statistics & df & p-value \\
\hline 6 & 4.36 & 5 & 0.499 \\
12 & 8.39 & 11 & 0.678 \\
18 & 14.40 & 17 & 0.639 \\
24 & 16.89 & 23 & 0.814 \\
\hline
\end{tabular}

In normality test, KolmogorovSmirnov statistic is 0.0822 with $p$-value more than 0.15 . So with alpha $5 \%$ we can conclude that error of first intervention model is white noise and normally distributed.

Based on parameter estimation results shown in Table 2, the first intervention model is: 


$$
\begin{aligned}
\sqrt{Z_{t}}= & 24,061.3 S_{49_{t-18}}+15,185.6 S_{49_{t-21}}+13,353.6 S_{49_{t-23}}-25,170.7 S_{49_{t-25}}- \\
& 22,501.9 S_{49_{t-27}}+35,618.2 S_{49_{t-34}}-19,157.4 S_{49_{t-36}}+15,824.5 S_{49_{t-39}}+ \\
& 15,087.1 S_{49_{t-40}}-12,939.4 S_{49_{t-43}}+13,499.4 S_{49_{t-45}}-31,942.9 S_{49_{t-48}}+ \\
& 13,498.9 S_{49_{t-50}}+\frac{595.7+(1-0.5451 B) \theta_{t}}{(1-B)}
\end{aligned}
$$

After we estimated first intervention model, we do forecast the data from January 2014 to September 2016 using that first intervention model. Then, we can build intervention response value for second intervention identification model.

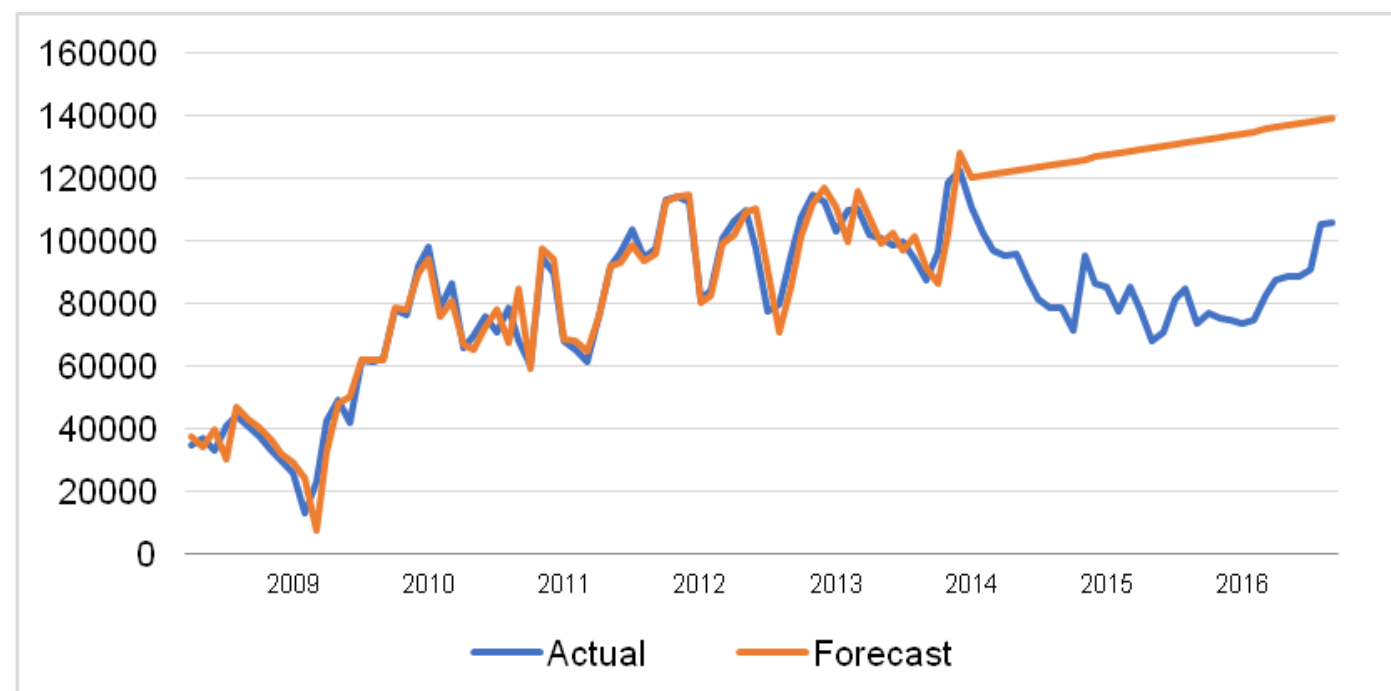

Figure 8. Actual Data and Forecast of First Intervention Model (in square root)

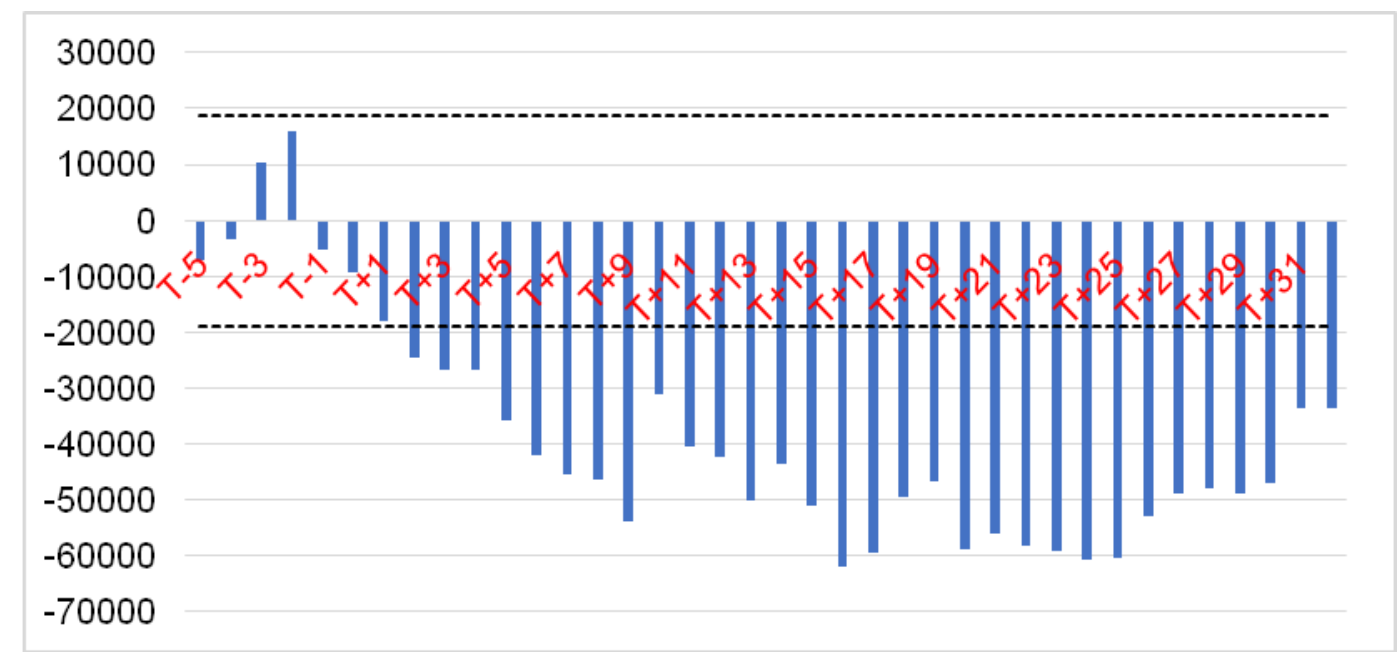

Figure 9. Response Values (in square root) after The Second Intervention 
The confidence interval in Figure 9 is based on RMSE of first intervention model, i.e. $\pm 18,831.76$. Intervention response value in Figure 9 shows the impact of the Air Pollution Prevention and Control Action Plan. Figure 9 also shows that response value of second intervention is negative. It means the order of intervention response explain the decrease in the volume of Indonesian coal exports due to Air Pollution Prevention and Control Action Plan.

Based on Figure 9, starts from $\mathrm{T}+2$ all the intervention response have lower value than the confidence interval. In this situation order $b_{2}$ is most likely $b_{2}=$ 2. But that order is not significant, so we try to estimate model with higher $b_{2}$. The response value shows that there is no specific pattern, so we can assume that order $r_{2}=0$.

Based on the results of parameter estimation, significance test, residual diagnostic and RMSE of many models, we conclude that the best model for second intervention is $b_{2}=9, s_{2}=(2$, 22), $r_{2}=0$. Parameter estimation and white noise error test of that model is shown in Table 4 and Table 5.
Table 4. Parameter Estimation Results for Second Intervention Model

\begin{tabular}{|c|c|c|c|}
\hline Parameter & Estimate & t stat & $p$-value \\
\hline $\mathrm{C}$ & 524.84 & 0.48 & 0.633 \\
\hline$\varphi_{1}$ & 0.5650 & 5.79 & 0.000 \\
\hline$\hat{\omega}_{0_{1}}$ & $24,294.9$ & 4.10 & 0.000 \\
\hline$\widehat{\omega}_{1_{1}}$ & $-1,5207.5$ & -2.47 & 0.016 \\
\hline$\widehat{\omega}_{2_{1}}$ & $-13,334.9$ & -2.09 & 0.039 \\
\hline$\widehat{\omega}_{\mathrm{a}_{1}}$ & $25,258.8$ & 3.97 & 0.000 \\
\hline$\widehat{\omega}_{4_{1}}$ & $22,253.8$ & 3.66 & 0.000 \\
\hline$\widehat{\omega}_{5_{1}}$ & $-35,376.1$ & -5.62 & 0.000 \\
\hline$\widehat{\omega}_{6_{1}}$ & $19,095.3$ & 3.10 & 0.003 \\
\hline$\widehat{\omega}_{7_{1}}$ & $-15,909.6$ & -2.25 & 0.027 \\
\hline$\widehat{\omega}_{\mathbb{Q}_{1}}$ & $-15,151.2$ & -2.14 & 0.035 \\
\hline$\hat{\omega}_{9_{1}}$ & $12,992.9$ & 2.11 & 0.038 \\
\hline$\hat{\omega}_{10_{1}}$ & $-13,477.9$ & -2.19 & 0.031 \\
\hline$\widehat{\omega}_{11_{1}}$ & $31,912.0$ & 5.18 & 0.000 \\
\hline$\widehat{\omega}_{12_{1}}$ & $-13,444.0$ & -2.22 & 0.029 \\
\hline$\omega_{\mathrm{O}_{2}}$ & $-17,527.6$ & -2.89 & 0.005 \\
\hline$\widehat{\omega}_{1_{2}}$ & $21,958.6$ & 3.54 & 0.001 \\
\hline$\hat{\omega}_{22}$ & $-12,192.1$ & -2.01 & 0.048 \\
\hline
\end{tabular}

Table 5. White Noise Test Results for $2^{\text {nd }}$ Intervention Model

\begin{tabular}{cccc}
\hline Lag & Ljung-Box statistic & df & p-value \\
\hline 6 & 6.42 & 5 & 0.268 \\
12 & 9.45 & 11 & 0.581 \\
18 & 14.37 & 17 & 0.641 \\
24 & 18.05 & 23 & 0.755 \\
\hline
\end{tabular}

In normality test, KolmogorovSmirnov statistic is 0.0805 with $p$ value $=0.1$. So with alpha $5 \%$ we can conclude that error of first intervention model is white noise and normally distributed. 


$$
\begin{aligned}
\sqrt{Z_{t}}= & 24,294.9 S_{49_{t-18}}+15,207.5 S_{49_{t-21}}+13,334.9 S_{49_{t-23}}-25,258.8 S_{49_{t-25}}- \\
& 22,253.8 S_{49_{t-27}}+35,376.1 S_{49_{t-34}}-19,095.3 S_{49_{t-36}}+15,909.6 S_{49_{t-39}}+ \\
& 15,151.2 S_{49_{t-40}}-12,992.9 S_{49_{t-43}}+13,477.9 S_{49_{t-45}}-31,912.0 S_{49_{t-48}}+ \\
& 13,444.0 S_{49_{t-50}}-17,527.6 S_{121_{t-9}}-21,958.6 S_{121_{t-11}}+12,192.1 S_{121_{t-31}}+ \\
& \frac{524.8+(1-0.56508) e_{t}}{(1-B)}
\end{aligned}
$$

The impact evaluation of intervention cannot be directly applied by using the intervention model in equation (15). This is because the original data has been transformed into square root form, so the impact of each intervention cannot be directly determined based on the estimated parameters derived from the intervention model. It can be explained by the following mechanism.

The model to be evaluated for the impact follows:

$$
Z_{t}=Z_{t}^{*}+N_{t}
$$

where $Z_{t}$ is the actual data, $Z_{t}^{*}$ is the effect of the intervention and $N_{t}$ is the ARIMA model. In addition, if the effect of an intervention is $\omega_{0}$, then the effect of the intervention can be written as:

$$
Z_{t}^{*}=Z_{t}-N_{t}=\omega_{0} \text {. }
$$

In this research, the data has been transformed into the square root of the original data. If $\bar{Z}_{\mathrm{t}}=\sqrt{\mathrm{Z}_{\mathrm{t}}}$, thus, the intervention model after transformation in this study is:

$$
\bar{Z}_{t}=\bar{Z}_{t}^{*}+\bar{N}_{t} .
$$

If we take the example for the first perceived impact on the first intervention $(T+18)$, i.e. $\bar{Z}_{t}^{*}=\omega_{0_{1}}$, so the effect after transformation can be written as:

$$
\bar{z}_{t}^{*}=\bar{z}_{t}-\bar{N}_{t}=\omega_{0_{1}} .
$$

Hence, the effect of the intervention on the original data is:

$$
\begin{aligned}
& Z_{t}^{*}=\bar{Z}_{t}^{2}-\bar{N}_{t}^{2} \\
& Z_{t}^{*}=\left(\bar{Z}_{t}^{*}+\bar{N}_{t}\right)^{2}-\bar{N}_{t}^{2} \\
& Z_{t}^{*}=\bar{Z}_{t}^{*}+2 \bar{Z}_{t}^{*} \bar{N}_{t} \neq \bar{Z}_{t}^{*} .
\end{aligned}
$$

Thus, the first perceived impact of the first intervention is not same as $\omega_{0_{1}}{ }^{2}$. It shows that parameter estimation on the transformed data cannot interpret the effect directly by reconstructing transformation (in this study, we cannot determine the impact by directly squaring the effect).

The impact calculation in this research can be done by using the following formula

$$
\hat{Z}_{t}^{*}=\widehat{\bar{Z}}_{t}^{2}+2 \widehat{\overline{Z_{t}^{*}}} \widehat{\bar{N}_{t}}
$$


where $\widehat{\overline{\mathrm{Z}_{\mathrm{t}}^{*}}}$ is the effect of transformed data, and $\widehat{\bar{N}}_{t}$ is the forecast values of ARIMA model of transformed data at the period where the impact is evaluated.

For example, at period $(T+18)$, effect of intervention model (transformed data) is $\overline{\mathrm{Z}}_{\mathrm{t}+18}^{*}=24,294.9$ and the forecast values of ARIMA model (transformed data) is $40,912.5$. Thus, the original impact at $(T+18)$ is: $\hat{\mathrm{Z}}_{\mathrm{t}+18}^{*}=(24,294.9)^{2}+(2 \times 24,294.9$ $\times 40,912.5$ )

$\hat{\mathrm{Z}}_{\mathrm{t}+18}^{*}=2,578,172,358$.

So the impact of the first intervention in July 2009 was $2,578,172,358 \mathrm{~kg}$ or 2.5 million metric tons.

Next, in $(T+21)$, the effect of intervention model (transformed data) is:

\section{$\overline{\mathrm{Z}}_{\mathrm{t}+21}^{*}=24,294.9-(-15,207.5)=$ $39,502.4$}

and forecast value of ARIMA model (transformed data) is $40,912.5$. Thus, the original impact at $(T+21)$ is:

$$
\begin{aligned}
\hat{\mathrm{Z}}_{\mathrm{t}+21}^{*}= & (39,502.4)^{2}+(2 \times 39,502.4 \\
& \times 42,334.8) \\
\hat{\mathrm{Z}}_{\mathrm{t}+21}^{*}= & 4,905,092,012 .
\end{aligned}
$$

So the impact of the first intervention in July 2009 was $4,905,092,012 \mathrm{~kg}$ or 4,9 million metric tons.
The impact of zero import tariff has been delayed for 18 months, it started at July 2009. That is, it took one and a half years for the intervention to deal a significant impact on Indonesian coal export volume to China. The length of the delay most likely caused by the global financial crisis endured by China along 2008 until early 2009. The magnitude of the first perceived intervention impact was the increase of Indonesian coal export volume to China by 2.5 million metric tons.

After that period the intervention response did not decrease or increase significantly, so the impact tended to be constant until September 2009. The impact began to increase in three periods after the first impact was felt, in October 2009 there was an increase of Indonesian coal export volume to China by 4.9 million metric tons. The impact increase again to 7.3 million metric tons in December 2009.

There are several changes in impact magnitude of zero import tariff to Indonesian coal export volume to China, summarized in Table 6. Started in March 2012 to December 2013, the impact of zero import tariff was the increase of Indonesian coal export volume to China by 6 million metric tons. 
According to impact calculations, zero coal import tariff implemented by China has positive impact to the volume of Indonesian coal exports to China, as the impacts tend to increase.
Since the impact is still large until just before the second intervention and even tend to increase, we can conclude that the impact of the policy is permanent.

Table 6. The Impact of Zero Import Tariff on Coal Commodities to Indonesian Coal Exports to China

\begin{tabular}{cc}
\hline Period & Impact (million metric tons) \\
\hline$T+18$ to $T+20$ & 2.578 \\
$T+21$ to $T+22$ & 4.905 \\
$T+23$ to $T+24$ & 7.365 \\
$T+25$ to $T+26$ & 3.200 \\
$T+27$ to $T+33$ & 0.509 \\
$T+34$ to $T+35$ & 5.604 \\
$T+36$ to $T+38$ & 2.603 \\
$T+39$ & 5.224 \\
$T+40$ to $T+42$ & 8.181 \\
$T+43$ to $T+44$ & 5.760 \\
$T+45$ to $T+47$ & 9.628 \\
$T+48$ to $T+49$ & 3.581 \\
$T+50$ to $T+71$ & 6.025 \\
\hline
\end{tabular}

Impact evaluation of the second intervention has similar as impact evaluation mechanism on the first intervention. The total intervention model to be evaluated for the impact follows:

$$
Z_{t}=Z_{1_{t}^{*}}^{*}+Z_{2_{t}^{*}}^{*}+N_{t}
$$

where $Z_{t}$ is the actual data, $Z_{1_{t}^{*}}^{*}$ is the effect of the first intervention, $Z_{2_{t}^{*}}^{*}$ is the effect of the first intervention, and $N_{t}$ is the ARIMA model. If the effect of an intervention is $\omega_{0}$, then the impact of the intervention can be written as:

$$
Z_{2_{t}^{*}}^{*}=Z_{t}-\left(Z_{1_{t}^{*}}^{*}+N_{t}\right)=\omega_{0}
$$

where $Z_{1_{t}^{*}}^{*}+N_{t}$ is first intervention model. If we denoted $Z_{1_{t}^{*}}^{*}+N_{t}$ as $Y_{t}$, then the original impact of the second intervention is:

$$
\hat{Z}_{2_{\mathrm{t}}}^{*}=\left(\hat{\bar{Z}}_{\mathrm{t}_{\mathrm{t}}}^{*}\right)^{2}+2 \hat{\bar{Z}}_{\mathrm{2}_{\mathrm{t}}^{*}}^{*} \hat{\bar{Y}}_{t}
$$

where $\widehat{\overline{\mathrm{Z}}_{\mathrm{t}}^{*}}$ is the effect of transformed data, and $\hat{\bar{Y}}_{t}$ is the forecast values of first intervention model of transformed 
data at the period where the impact is evaluated.

At period $(T+9)$, effect of intervention model (transformed data) is $\hat{\overline{\mathrm{Z}}}_{\mathrm{2}_{\mathrm{t}+9}^{*}}^{*}=-17,527.6$ and forecast value of first intervention model (transformed data) is $125,659.37$. Thus, the original impact of second intervention at $(T+9)$ is

$$
\begin{aligned}
\hat{\mathrm{Z}}_{\mathrm{t}_{\mathrm{t}+9}^{*}=} & (-17,527.6)^{2}+(2 \times \\
& (-17,527.6) \times 125,659.37) \\
\hat{\mathrm{Z}}_{\mathrm{t}_{\mathrm{t}+9}^{*}=} & -4,097,797,585 .
\end{aligned}
$$

So the impact of the second intervention in October 2014 was $4,097,797,585 \mathrm{~kg}$ or decrease by 4.1 million metric tons.

At period $(T+11)$, effect of intervention model (transformed data) is:

$\widehat{\overline{\mathrm{Z}}}_{2_{\mathrm{t}+11}^{*}}^{*}=-17,527.6-21,958.6=$ $-39,486.1$

and forecast value of first intervention model (transformed data) is $126,850.82$. Thus, the original impact of second intervention at $(T+11)$ is:

$$
\begin{gathered}
\hat{\mathrm{Z}}_{\mathrm{2}_{\mathrm{t}+11}^{*}}^{*}=(-39,486.1)^{2}+(2 \times \\
(-39,486.1) \times 126,850.82) \\
\hat{\mathrm{Z}}_{\mathrm{2}_{\mathrm{t}+11}^{*}}^{*}=-8,458,536,233 .
\end{gathered}
$$

So the impact of the second intervention in December 2014 was $8,458,536,233 \mathrm{~kg}$ or decrease by 8.4 million metric tons.
At period $(T+31)$, effect of intervention model (transformed data) is:

$$
\begin{aligned}
& \hat{\overline{\mathrm{Z}}}_{\mathrm{2}_{\mathrm{t}+\mathrm{BI}}}^{*}=-17,527.6-21,958.6+ \\
& 12,192.1=-27,294
\end{aligned}
$$

and forecast value of first intervention model (transformed data) is 138,765.36. Thus, the original impact of second intervention at $(T+31)$ is:

$$
\begin{gathered}
\hat{\mathrm{Z}}_{\mathrm{2}_{\mathrm{t}+\mathrm{BI}}^{*}}=(-27,294)^{2}+(2 \times \\
(-27,294) \times 138,765.36) \\
\hat{\overline{\mathrm{Z}}}_{\mathrm{2}_{\mathrm{t}+\mathrm{BI}}^{*}}=-6,829,961,035
\end{gathered}
$$

So the impact of the second intervention in August 2016 was $6,829,961,035 \mathrm{~kg}$ or decrease by 6,8 million metric tons.

The impact of Air Pollution Prevention and Control Action Plan has been delayed for 9 months, it started at October 2014. It took almost a year for the intervention to deal a significant impact on Indonesian coal export volume to China. During that period, Air Pollution Prevention and Control Action Plan decrease the Indonesian coal export volume to China by 4.1 million metric tons.

Intervention response changed in the two subsequent periods of December 2014. Intervention response change started from January 2015 to July 2016 was not statistically significant, so it can be concluded that 
from December 2014 to July 2016 the average impact of the Air Pollution Prevention and Control Action Plan decrease Indonesian coal export to China by 8.4 million tons. Started from August 2016 to September 2016, Air Pollution Prevention and Control Action Plan decrease Indonesian coal export volume to China by 6.8 million metric tons.

The impact of Air Pollution Prevention and Control Action Plan is permanent, because the response value tended to increase since the first time when the impact was significant. Then in January 2015 began to constant for the next 20 periods. Although, in the last two periods of research, the magnitude of the impact was decreased. It means after the impact is constant for 20 months, it remains big enough in the last two periods of this research. So we can call it permanent effect until the end period of this study.

The results of this study showed that zero import tariff will increase the import volume of country that applied the policy, and commodity usage restriction (it means there is restriction on impor) policy for a commodity will decrease import volume of country that applied the policy. The results are according to Krugman \& Obsfeld (2008) theories.

\section{CONCLUSION AND POLICY RECOMMENDATION}

Based on results and discussion, we conclude that both zero coal import tariff and Air Pollution Prevention and Control Action Plan implemented by China have permanent impact on Indonesian coal exports to China. Although the impact of Air Pollution Prevention and Control Action Plan appears to decrease at the end of the period of this research. Zero coal import tariff has positive effect, while Air Pollution Prevention and Control Action Plan has negative effect. The delay of zero coal import tariff impact is 18 month, while the delay of Air Pollution Prevention and Control Action Plan impact is 9 month.

Policy recommendation we can suggest is the implementation of policy about minimum standards of coal quality that may be produced. Thus, producers will improve their quality control analysis in monitoring the quality of the produced coal. So, Indonesian coal exports quality will able to adjust market demand specification from importing countries that implement policies about pollution control. In addition, this policy may have impact 
on reducing domestic air pollution levels.

\section{ACKNOWLEDGMENT}

We would like to thank all those who have assisted us in the process of building this paper, especially for BPS that has provided us the data for research.

\section{REFERENCES}

Box, G., \& Tiao, C. (1975). Intervention Analysis with Applications to Economic and Environtmental Problems. Journal of The American Statistical Association, Vol. 70(349), pp. 70-79.

BPS. (2016). Neraca Energi Indonesia 2011-2015. Jakarta: Badan Pusat Statistik.

BPS. (2017). Ekspor Batu Bara Menurut Negara Tujuan Utama, 2002-2015. Accesed on 1 April 2017 from https://www.bps.go.id/statictable/2014/ 09/08/1034/ekspor-batu-bara-menurutnegara-tujuan-utama-2002-2015.html

Clean Air Asia. (2015). China Air 2015: Air Pollution Prevention and Control Progress in Chinese Cities. Clean Air Asia.

Cai, Si., Wang, Y., Zhao, B., Wang, S., Chang, X., Hao, J. (2016). The impact of the "Air Pollution Prevention and Control Action Plan" on $\mathrm{PM}_{2.5}$ concentrations in Jing-Jin-Ji region during 2012-2020. Science of The Total Environment, Vol. 280, pp. 197209.

Cestepe, H., Yildirim, E., Bahtiyar, B. (2015). The Impact of Trade Liberalization on the Export of MENA Countries to OECD Trade Partners. Science of The Total Environment, Vol. 23, pp. 1440-1445.

Enders, W. (2004). Applied Econometric Time Series Second Edition. New Jersey: John Wiley \& Sons, Inc.
Dianniar, U. (2013). The Impact of Free Trade Agreements on Indonesia's Agricultural Trade Flows: An Application of the Gravity Model Approach. Thesis. The Hague: Erasmus University Rotterdam, Netherlands.

IEA. (2016). World Energy Balance. International Energy Agency.

Hoque, M. M., Yusop, Z. (2012). Impacts of Trade Liberalization on Export Performance in Bangladesh: An Empirical Investigation. South Asia Economic Journal, Vol. 13(2).

Imburno, M. (2016). China and WTO liberalization: Imports, Tariffs and Nontariff barriers. China Economic Review, Vol. 38, pp. 222-237.

Ismail, Z., Suhartono, Yahaya, A., R. Efendi. (2009). Intervention model for analyzing the impact of terrorism to tourism industry. Journal of Mathematics and Statistics, Vol. 5, pp. 322-329.

Jin, Y., Andersson, H., Zhang, S. (2016). Air Pollution Control Policies in China: A Retrospective and Prospects. Int $J$ Environ Res Public Health, Vol. 13(12).

Krugman, P. R., \& Obstfeld, M. (2008). International Economics: Theory and Policy 8th Edition. New Jersey: Prentice Hall.

Lee, M. H., Suhartono, \& Sanugi, B. (2010). Multi Input Intervention Model for Evaluating the Impact of the Asian Crisis and Terrorist Attacks on Tourist Arrivals. Matematika, Vol. 26, pp. 83106.

Liu, Z., Guan, D.B., Wei, W., Davis, S.J., Ciais, P., Bai, J., Peng, S.S., Zhang, Q., Hubacek,K., Marland, G., Andres, R.J., Crawford-Brown, D., Lin, J.T., Zhao, H.Y., Hong, C.P.,Boden, T.A., Feng, K.S., Peters, G.P., Xi, F.M., Liu, J.G., Li, Y., Zhao, Y., Zeng, N., He,K.B. (2015). Reduced carbon emission estimates from fossil fuel combustion andcement production in 
China. Nature, Vol. 524 (7565), pp. 335-338.

Novianti, P. W., \& Suhartono. (2009). Permodelan Indeks Harga Konsumen Indonesia dengan Menggunakan Model Intervensi Multi Input. Buletin Ekonomi, Moneter, dan Perbankan, Juli 2009, Vol. 12(1), pp. 83-104.

Okabe, M \& Urata, S. (2014). The Impact of AFTA on Intra-AFTA Trade. Journal of Asian Economics Vol. 35, pp. 12-31.

Siegel, Sidney. (1992). Nonparametric Statistics for the Behavioral Sciences. New York: John Wiley \& Sons, Inc.
Vanhnalat, B., Kyophilavong, P., Phonvisay, A., \& Sengsourivong, B. (2015). Assessment the Effect of Free Trade Agreements on Exports of Lao PDR. International Journal of Economics and Financial Issues, Vol. 5(2), pp. 365-376.

Wei, W. W. (2006). Time Series Analysis: Univariate and Multivariate Methods 2nd edition. USA: Pearson Education, Inc. 
